\title{
Efficacy of different instruments for the mechanical removal of the smear layer in immediate post preparations: a comparative study
}

\author{
Marcela L. Roitman, Laura B. Pinasco, Romina Loiacono, Valeria C. Panetta, Carolina A. \\ Anaise, Pablo A. Rodríguez
}

Universidad de Buenos Aires. Facultad de Odontología. Cátedra de Endodoncia. Buenos Aires, Argentina

\begin{abstract}
Adhesively cemented fiber-reinforced composite posts are commonly used to reconstruct endodontically treated teeth. Adhesion to intraradicular dentin is complex, and close contact between the resin cements and the dentin is essential. The removal of the smear layer following post space preparation (secondary smear layer) can improve this integration. Different mechanical systems have been used to activate the irrigant inside the root canal. The purpose of this study was to compare, ex-vivo, the removal of the smear layer from the walls of the immediate post space preparation by the action of three mechanized instruments. Forty premolar specimens with a single root canal were selected, endodontically treated, and shaped for glass fiber post cementation with Peeso reamer \#1 (Dentsply Sirona, Switzerland) and Macrolockfinishing drill \#3 (RTD, France). The specimens were randomly divided into 4 groups $(n=10)$ : Group $C$ (control); Group PUI (passive ultrasonic irrigation); Group CEP (Rotoprox brush, Hager Werken, Germany) and Group XP (XP-endo Finisher, FKG Dentaire, Switzerland). Post space
\end{abstract}

surfaces were cleaned with $3 m L$ of distilled water; each specimen root split longitudinally to expose the root canals, and prepared for examination in a scanning electron microscope at magnification 350X. The results were analyzed using the Kruskal-Wallis and Friedman tests $(p>0.05)$. RESULTS: Statistically significant differences $(p<0.05)$ were found between Groups $C$ and XP in all three root regions, but not between Groups C, CEP and PIU. Of these, Group CEP showed a better trend in the results of the coronary and middle thirds, without significant difference with Group XP. Although it was difficult to achieve a clean dentin surface after preparation for the fiberglass post, the XP-endo Finisher was the most efficient in removing secondary smear layer, followed by the Rotoprox conical brush.

Received: September 2020; Accepted May 2021.

Keywords: Endodontics - Smear Layer - Root Canal Preparation.

\section{Eficacia de diferentes instrumentos para la remoción mecánica del barro dentinario en preparaciones inmediatas para poste: estudio comparativo}

\begin{abstract}
RESUMEN
La fijación adhesiva de postes de fibra es un procedimiento habitual en la rehabilitación de piezas tratadas endodónticamente. La adhesión a dentina radicular resulta compleja, y es fundamental el intimo contacto entre el medio resinoso y el sustrato dentinario. La eliminación del barro dentinario posterior a la preparación del anclaje intrarradicular podría mejorar esta integración. Para lograr una adecuada limpieza, se han implementado diferentes sistemas mecánicos para la activación del irrigante en el interior del conducto radicular.

El objetivo del presente trabajo fue comparar ex-vivo la remoción del barro dentinario de las paredes de la preparación inmediata para poste por acción de tres instrumentos mecanizados. Se utilizaron 40 premolares inferiores unirradiculares tratados endodónticamente y preparados para anclaje intrarradicular con fresa Largo \#1 (Dentsply Sirona, Suiza) y fresa piloto del sistema Macrolock Azul (RTD, Francia). Las piezas fueron divididas aleatoriamente en grupos $(n=10)$ : $G C$ (control); $G$ PIU (irrigación pasiva ultrasónica); G CEP (cepillo Rotoprox cónico, Hager Werken, Alemania) y GXP (XP-endo Finisher,
\end{abstract}

FKG Dentaire, Suiza). Las preparaciones fueron irrigadas con $3 \mathrm{ml}$ de agua destilada; las piezas fueron seccionadas longitudinalmente en sentido proximal, metalizadas y observadas al microscopio electrónico de barrido a 350X. Las imágenes fueron analizadas bajo categorización ordinal y mediante las pruebas de Kruskall - Wallis y Friedman, estableciendo un $p>0, o 5$. Existió diferencia significativa $(p<0,05)$ entre el grupo $G C y G$ $X P$ en todos los tercios radiculares, pero no entre $G C, G C E P$ y G PIU. Entre estos grupos, el G CEP marcó una tendencia a mejores resultados en tercio coronario y medio sin diferencia significativa con el G XP. A pesar de la dificultad para lograr una superficie dentinaria limpia luego de preparaciones para poste, el XP-endo Finisher fue el más eficiente en la remoción del barro dentinario secundario, seguido por el cepillo cónico Rotoprox.

Palabras clave: endodoncia - barro dentinario - preparación del conducto. 


\section{INTRODUCTION}

Adhesive bonding of fiber-reinforced resin posts is a usual procedure in the rehabilitation of endodontically treated teeth ${ }^{1}$.

Bonding to root dentin is complex, and requires close contact between the resin cement and the dentin substrate. Root post space preparation with Gates Glidden and pilot burs produces a large amount of secondary smear layer made up of remains of endodontic sealer, gutta-percha plasticized by frictional heat, and inorganic components ${ }^{2}$. This thick smear layer covering root canal walls jeopardize the effective adhesion of the cement ${ }^{3,4}$, even more when self-etching resin-based cements are used with adhesive protocols that do not include rinses and are unable to penetrate it. Neither can acid-etch techniques always remove this smear layer successfully ${ }^{1,2}$. The absence of chemical bonding between the polyisoprene component of the guttapercha remaining on root canal walls following deobturation for the post and the methacrylate of the resin cement may compromise bonding to dentin ${ }^{5}$.

Certain factors such as endodontic obturation technique and time of de-obturation / post preparation may modify the quantity of endodontic material remaining on the root canal walls.

Thermoplastic obturation techniques such as the hybrid technique, systems with carriers or injected gutta-percha fill the irregularities of the root canal better than single-cone and lateral condensation techniques, but make it more difficult to remove material later from inaccessible areas ${ }^{6,7}$.

Post space preparation can be immediate or delayed until after endodontic treatment. Immediate preparation provides greater benefits regarding control of apical seal and easier removal of remains of yet unhardened endodontic material ${ }^{6,7,8}$.

Dentinal smear layer is often removed by means of a combination of a chelating irrigant solution such as EDTA plus a proteolytic solution such as sodium hypochlorite. However, most studies have shown that these irrigant solutions are unable to remove the smear layer completely, especially when used passively, without mechanical activation ${ }^{9}$. Different methods can be used to activate irrigant solutions and achieve mechanical cleansing of the secondary smear layer and obturation remnants. These include low-speed rotary brushes, ultrasonic endodontic tips, cotton-wrapped files with alcohol, polymer tips on sonic devices such as the EndoActivator
(Dentsply Sirona) and more recently, a nickeltitanium instrument designed for final cleansing of endodontic preparation, called XP-endo Finisher (FKG Dentaire, Switzerland).

A conical or cylindrical rotary brush is an inexpensive, simple-to-use instrument. Its use is not limited to endodontics, and it can also be used for cleaning interproximal spaces during dental prophylaxis, mounted on a micromotor and conventional lowspeed contra-angle.

Passive ultrasonic irrigation, described by Weller in $1980^{10}$, uses a smooth, thin stainless steel file to activate the irrigant inside the root canal. This technique is based on the premise that the energy released by the instrument improves the physicochemical properties of irrigant solutions by cavitation and acoustic flow ${ }^{11}$.

The XP-endo Finisher file (FKG, Dentaire, Switzerland) has recently appeared on the dental market. It is made from a new nickel-titanium alloy that enables it to act inside the root canal by expanding up to $6 \mathrm{mms}$ more than its diameter, thereby reaching all the anatomy. The file is straight in its M-phase at ambient temperature or when cooled. When exposed to body temperature (within the root canal) its shape changes due to its molecular memory, to A-phase, enabling it to access and clean various parts of the root canal such as isthmuses and resorptions that other instruments cannot reach. Comparative studies on the use of the XP-endo Finisher file for post-endodontic instrumentation report promising results ${ }^{12,13}$.

The aim of this study was to determine which of the three instruments used (passive ultrasonic irrigation, rotatory brush and XP-endo Finisher) is most efficient in removing the secondary smear layer from the post preparation space, independently of the irrigant solution.

\section{MATERIALS AND METHODS}

This was an ex vivo, controlled study. Forty human lower premolars that had been extracted for orthodontic or periodontal reasons were selected. Sampling was probabilistic and random.

Inclusion criteria: Lower premolars with total length $21 \mathrm{~mm}$ to $23 \mathrm{~mm}$; apex fully developed; without carious lesions; root canal single, straight, patent to glide path preparation, not excessively oval (canal was considered excessively oval 
when radiograph showed vestibular-lingual and mesiodistal dimensions in the middle third with a ratio greater than 2:1).

Exclusion criterion: lower premolars with excessively oval anatomy.

Clinical crowns were sectioned $2 \mathrm{~mm}$ above the proximal cementoenamel junction. Conventional openings were made, root canal glide paths were prepared, and working length of each specimen was determined as $1 \mathrm{~mm}$ before the apical foramen, using a \#15 K-file. Root canals were instrumented with ProTaper Next system (Dentsply Maillefer, Ballaigues, Switzerland) up to file X3, irrigating each instrument change with $2 \mathrm{ml}$ of $2.5 \%$ sodium hypochlorite solution. Final irrigation was done with $17 \%$ EDTA for 60 seconds and $2.5 \%$ sodium hypochlorite for 30 seconds, irrigating with $3 \mathrm{ml}$ distilled water in between. The apical thirds of the root canals were obtured with tapered guttapercha cones, AH Plus endodontic sealer (Dentsply Sirona, Switzerland) and warm vertical compaction technique with Calamus Dual (Dentsply Sirona, Ballaigues, Switzerland). Post spaces were prepared immediately with a Largo \#1 bur (Dentsply Maillefer, Ballaigues, Switzerland) and \#1, 2 y 3 calibration burs of the Macro-lock XRO (RTD, France) for the fiber posts, depth $12 \mathrm{~mm}$. Root canals were irrigated with $3 \mathrm{ml}$ of distilled water using a syringe and 1" Terumo $25 \mathrm{G}$ needles each time the instrument was changed. Samples were divided randomly into four groups $(\mathrm{n}=10)$ and labelled according to the subsequent cleaning protocol to be applied: Group C (control); Group PIU (passive ultrasonic irrigation); Group CEP (conical Rotoprox brush, Hager Werken, Germany) and Group XP (XP-endo Finisher, FKG, Dentaire, Switzerland).

Group $\mathrm{C}$ was irrigated with distilled water but no mechanical cleaning system was used after preparation with pilot burs. For the rest of the experimental groups, each selected instrument was used following the manufacturer's instructions for 30 seconds with distilled water inside the root canal. For Group PIU, a fine stainless steel (white) spreader tip mounted on an adaptor for the Woodpecker ultrasound unit (China) was used at $20 \%$ power. For Group CEP, a brush mounted on a micromotor and contra-angle was used at low speed, with in-andout motion, against root canal walls. For Group XP, samples were instrumented in an oven at $37{ }^{\circ} \mathrm{C}$ to simulate body temperature and allow the instrument's nickel-titanium austenitic phase to be expressed. Then a Teflon roll was placed in each specimen to fill the root canal space, two grooves were carved in the proximal root faces using a diamond disc without invading the endodontic space, and the samples were frozen at $-70^{\circ} \mathrm{C}$ for a week, in order to make it easier to section the teeth. The samples were split using a chisel and hammer in order not to create any new smear layer that might alter observations. Half of each sample was selected and a fine-tip marker was used to make marks beside the root canal at $3 \mathrm{~mm}$ (coronary third), $6 \mathrm{~mm}$ (cervical third) and $9 \mathrm{~mm}$ (apical third) from the coronary reference, to enable identification of the areas to be observed under scanning electron microscope. Microphotographs of the center of the root canal were taken of each third at $350 \mathrm{X}$ magnification.

The following scores was applied for evaluation ${ }^{14}$ (Fig.1):

1: No smear layer.

2: Few areas covered in smear layer, with many open dentinal tubules.

3: Most areas covered in smear layer, with few visible open dentinal tubules.

4: All areas covered in smear layer.

The images were analyzed independently by two calibrated evaluators. If the evaluators disagreed, they analyzed the image together until they reached a consensus. For statistical analysis, values were calculated per root thirds and per group. KruskallWallis and Friedman tests were applied. Significance level was established as $\mathrm{p}<0.05$ for all cases.

\section{RESULTS}

Observation by SEM showed presence of dental smear in all samples, thereby corroborating the difficulty in removing secondary smear layer from root canal walls by means of all the systems tested. In Group C (Fig. 2 a, b, c), there was a thick layer of amorphous smear layer completely covering the observation area in all three root thirds. In Group PIU (Fig. 3 a, b, c), there was smear layer covering the entire dentin surface with presence of scratch marks in different directions on the cervical and middle thirds (Fig. 3 a, b). In Group XP, most areas were covered with smear layer and there were few visible open dentinal tubules (Fig. 4 a, b, c). In Group CEP (Fig. 5 a, b, c) there was a thin, uniform, adhered smear layer covering the observation area, with a few visible open dentinal tubules and some 


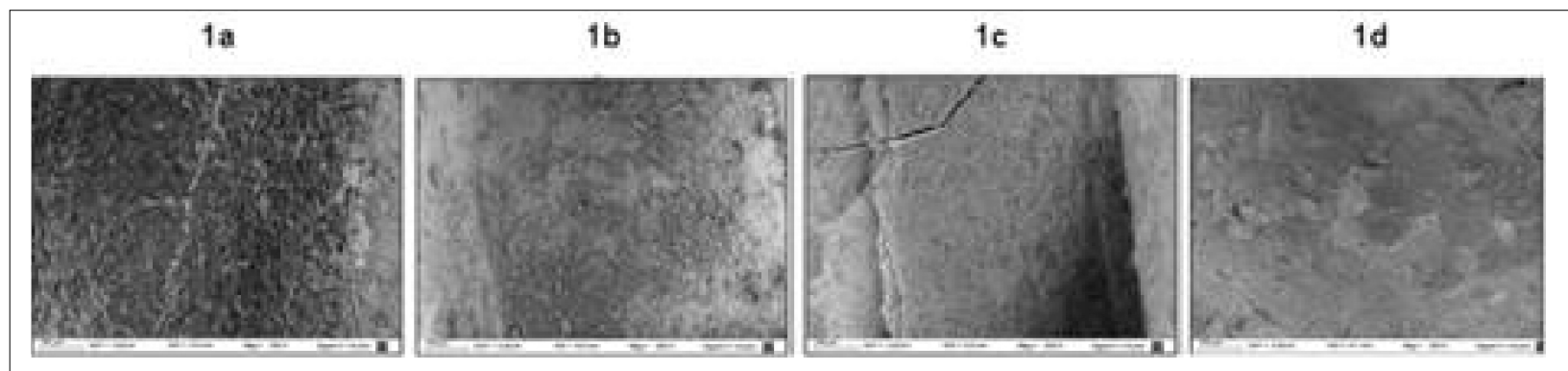

Fig. 1: Scanning electron microphotograph (350X) scores. a: Score 1, no smear layer. b: Score 2: few areas covered in smear layer, with many open dentinal tubules. c: Score 3, most areas covered in smear layer, with few visible open dentinal tubules. d: Score 4, all areas covered in smear layer.

$2 a$

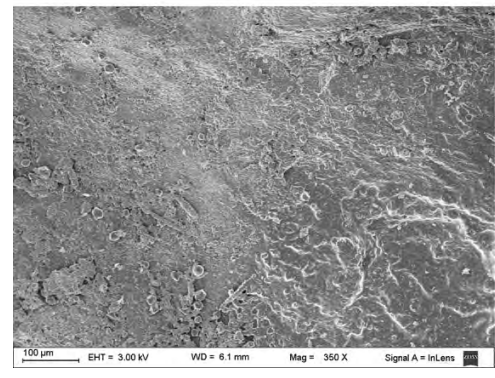

$2 b$

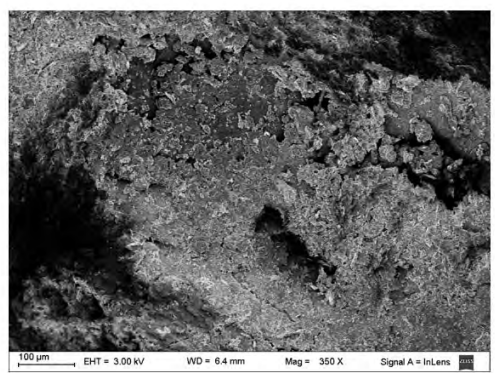

$2 c$

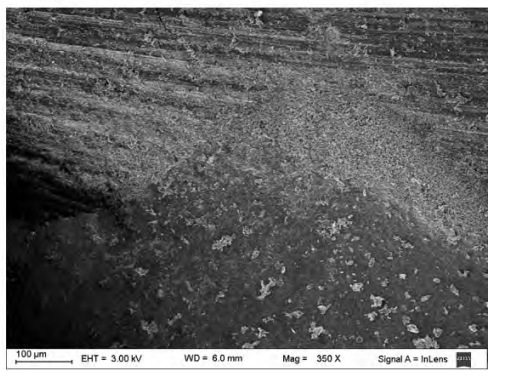

Fig. 2: Scanning electron microphotographs (350X) for observation of secondary smear layer removal in the control group (no mechanical cleaning). a: cervical third, there is a dense, irregular smear layer covering the dentin surface entirely. $b$ : middle third, persistence of a thick, amorphous smear layer with many debris particles of different sizes hiding dentin tubule openings. c: apical third with dense smear layer covering the entire area, with presence of loose debris particles and longitudinally oriented grooves.

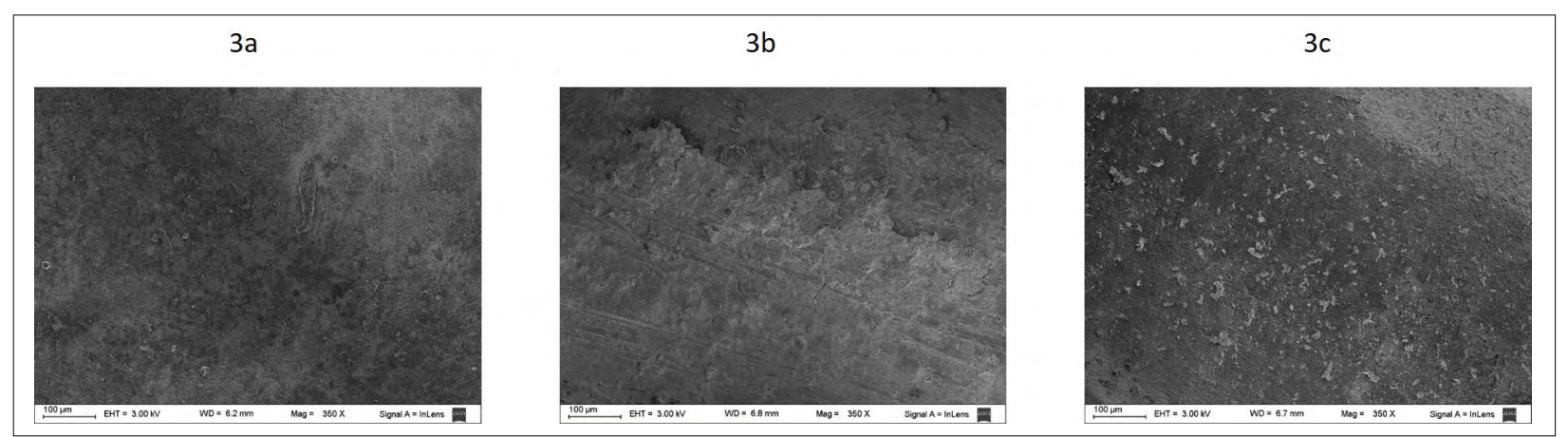

Fig. 3: Scanning electron microphotographs (350X) for observation of secondary smear layer removal in Group PIU (passive ultrasonic irrigation). a: cervical third, there is a thick, even smear layer completely covering the dentin surface. $b$ : middle third, scratches on root canal walls. $c$ : apical third, with persistence of a thin smear layer and a few small debris particles, approximately $20 \mu \mathrm{m}$ across, scattered over the surface.

light scratch marks in the apical third (Fig. 5c).

Data and mean values are provided in Table 1.

In Groups $\mathrm{C}$ and XP, no statistically significant difference was found between thirds $(\mathrm{p}>0.05)$. Within Group CEP, there was a significant difference between the middle third and the apical third. Within Group PUI, there was a significant difference between the middle third and the coronary third. There were statistically significant differences between Groups XP and C for all thirds. However, the difference was not statistically significant between Groups CEP, PIU and C, although a trend to better removal of smear layer was noted in Group CEP, for all thirds. There was no significant difference between groups CEP and XP for the middle and coronary thirds ( $p>0.05)$ (Figs. 2- 5).

In some samples, there were light scratch marks on the root canal surface. This was noted in all experimental 


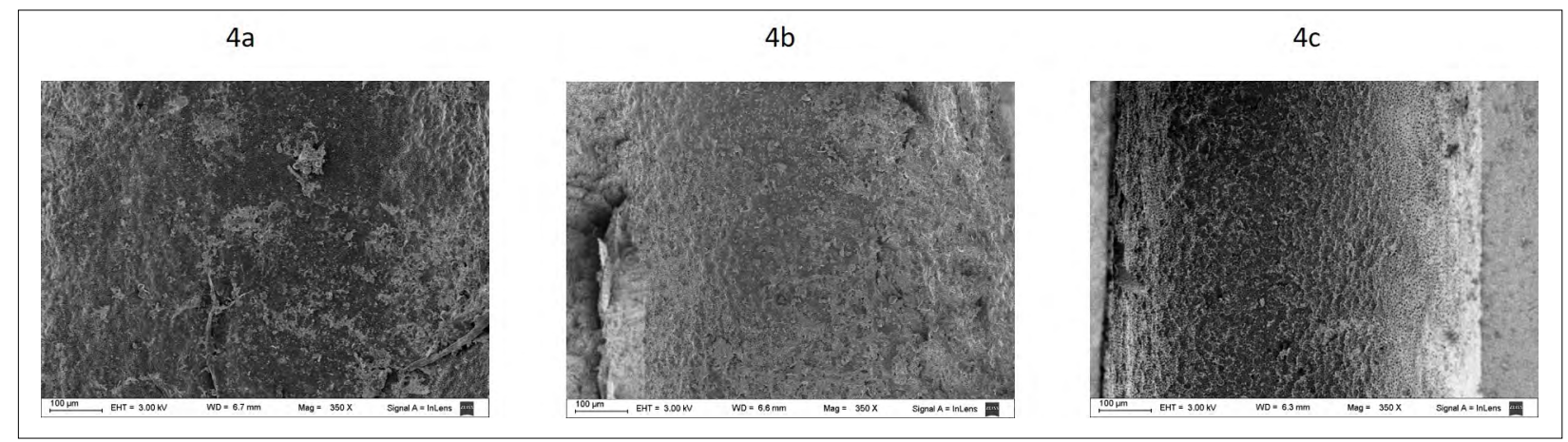

Fig. 4: Scanning electron microphotographs (350X) for observation of secondary smear layer removal in Group XP (XP-endo Finisher). a: cervical third: presence of smear layer covering dentin surface, scattered particles and a few free areas where dentin tubule openings are visible. b: middle third, persistence of smear layer, less loose debris and openings of some dentin tubules visible. c: apical third, many dentin tubules open and some areas covered in smear layer.

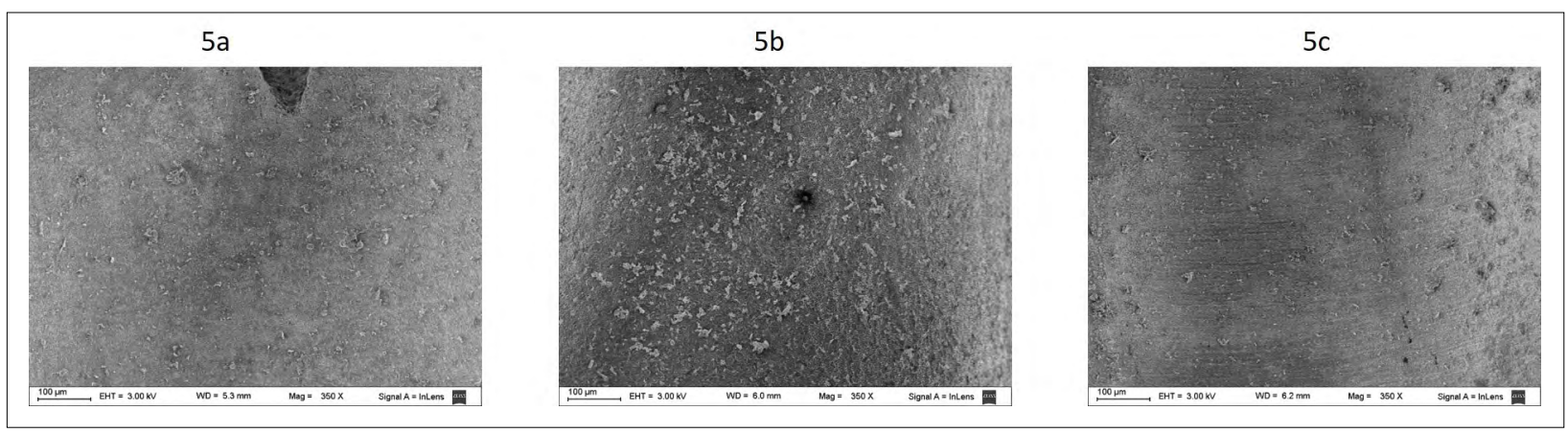

Fig. 5: Scanning electron microphotographs (350X) for observation of secondary smear layer removal in the Group CEP (Rotoprox conical brush). a: cervical third, presence of a smear layer of even thickness completely covering the dentin surface with a few small, scattered debris particles. b: middle third, mostly areas with open dentin tubules, with presence of debris particles approximately $25 \mu \mathrm{m}$ across scattered on the surface. $\mathrm{c}$ : apical third: thinned smear layer and some slight scratches, close together.

\begin{tabular}{|c|c|c|c|c|c|c|}
\hline \multirow{2}{*}{ Third } & \multirow{2}{*}{ Group } & \multicolumn{5}{|c|}{ Score } \\
\hline & & 1 & 2 & 3 & 4 & Mean \\
\hline \multirow{4}{*}{ Coronal } & Control (a) & 0 & 0 & 0 & 10 & 4.0 \\
\hline & $\operatorname{CEP}(a, b)$ & 1 & 1 & 0 & 8 & 3.5 \\
\hline & PIU (a) & 0 & 0 & 1 & 9 & 3.9 \\
\hline & $X P(b)$ & 1 & 1 & 5 & 3 & 3.0 \\
\hline \multirow{4}{*}{ Middle } & Control (a) & 0 & 1 & 0 & 9 & 3.8 \\
\hline & $\operatorname{CEP}(a, b)$ & 0 & 3 & 3 & 4 & 3.1 \\
\hline & PIU (a) & 1 & 0 & 3 & 6 & 3.4 \\
\hline & $\mathrm{XP}(\mathrm{b})$ & 2 & 2 & 5 & 1 & 2.5 \\
\hline \multirow{4}{*}{ Apical } & Control (a) & 0 & 0 & 1 & 9 & 3.9 \\
\hline & CEP (a) & 0 & 1 & 2 & 7 & 3.6 \\
\hline & PIU (a) & 0 & 0 & 1 & 9 & 3.9 \\
\hline & XP (b) & 0 & 3 & 6 & 1 & 2.8 \\
\hline
\end{tabular}

CEP: Rotoprox brush; PIU: passive ultrasonic irrigation; XP: XP-endo Finisher.

Differences between groups identified with the same letter between brackets in each third are not statistically significant (Kruskall-Wallis; $p>0.05$ ). 
groups, most frequently in the apical and middle thirds. Scratch marks were found, in descending order, in Groups PIU, CEP, and XP, with the same amount in Groups XP and C (Figs. 2c, 3b, 5c).

\section{DISCUSSION}

When luting a fiber post, it is essential to have clean dentin walls free from debris and endodontic filling remnants. It is therefore recommendable to implement a combination of mechanical and chemical cleaning actions prior to cementing ${ }^{1,9}$. This is even more important when dealing with oval-shaped canals such as those in single-rooted premolars and canines, which have more pronounced elliptical and irregular shape towards the free faces of the tooth, resulting in areas that retain endodontic sealer and gutta-percha ${ }^{14}$.

The current study used distilled water instead of irrigants in order to evaluate the mechanical action only - without the chemical action of irrigants - for each system tested. In this regard, all the systems evaluated presented difficulty in completely removing the smear layer from all thirds.

In this scenario, the XP-endo Finisher achieved the best cleaning results in post space preparations and was efficient in all root thirds, even in the apical third, which is so difficult to access due to the small diameter of the post space. Thus, our studies agree with Sanabria ${ }^{11}$, who reports that the XP-endo Finisher works better than ultrasound to remove smear layer from endodontic preparations. The XP-endo Finisher is a thin, flexible instrument designed specifically for final cleaning during surgical preparation and it reaches small, constricted areas with diameters smaller than spaces prepared for root posts. In contrast, Azimian ${ }^{15}$ reports that the XP-endo Finisher combined with EDTA and sodium hypochlorite used after the final irrigation during surgical preparation is not superior to the same protocol without activation, thereby dismissing the mechanical action of the instrument per se.

In agreement with Coniglio ${ }^{2}$, our study found very similar values between Groups PUI and C in all root thirds when distilled water was used. Consideration should be given to ultrasound intensity, which manifests in the oscillation amplitude of the instrument, application time, volume and concentration of irrigant. Although ultrasound has demonstrated good results in removing debris in combination with EDTA as a final step in surgical preparation of an endodontic treatment ${ }^{16}$, Poletto et al. conclude that ultrasonic activation of irrigant solutions did not contribute to a more effective removal of smear layer after root post preparation'. There are different possible explanations for this: Coniglio et al. ${ }^{2}$ suggest that ultrasound may compact debris particles laterally against root canal walls, Guo et al. ${ }^{17}$ refer to the creation of new smear layer due to the scratch marks left by the instrument on dentin walls, while $\mathrm{Chen}^{18}$ assumes that the discrepant results among studies are related to the different sizes of the preparations in the models used.

Although it was not one of the aims of this study, we noted the presence of scratch marks on some samples in all experimental groups, including Group C, where only passive irrigation of the dental smear was performed after root post space preparation, without activating the distilled water by any mechanized system. This suggests that, at least in Group C, these marks may have been caused by the Largo or pilot bur of the post system during preparation of the root bed. In agreement with Guo et al. ${ }^{18}$, we noted more scratch marks in Group PIU, despite the precautions taken to avoid touching root canal walls upon activating the thin tip of the ultrasound.

In contrast to Goldberg ${ }^{19}$, we found that although there was no significant difference between rotary brush and control groups, the rotary brush tended to provide cleaner results, approaching those of the XP-endo Finisher group in the middle and coronary thirds. This difference between the studies is probably related to differences in the endodontic obturation techniques used. We filled only the apical third using single cone and warm vertical compaction technique, immediately preparing the post space and cleaning unset remains of sealant from root canal walls, which must have facilitated the removal of material. It is accepted that the continuous vertical condensation technique provides better obturation quality in the coronary third because the thermoplasticized gutta-percha provides better filling of the irregularities in the root canal ${ }^{20}$; nevertheless, in the middle and apical thirds, the single cone and the continuous vertical compaction techniques provide similar sealing ${ }^{21}$.

Despite the difficulties involved in achieving a completely clean dentinal surface after post space preparation, the XP-endo Finisher instrument was the most efficient for removal of secondary smear layer, followed by the Rotoprox conical brush. 


\section{ACKNOWLEDGMENTS}

We thank Dr. Ricardo Macchi for the statistical analysis in this study.

\section{DECLARATION OF CONFLICTING INTERESTS}

The authors declare no potential conflicts of interest regarding the research, authorship, and/or publication of this article.

\section{FUNDING}

None

\section{CORRESPONDENCE}

Dr. Valeria Cecilia Panetta

Paso 93 Avellaneda C.P 1870

Pcia.Buenos Aires, Argentina panettavaleria@hotmail.com

\section{REFERENCES}

1. Serafino C, Gallina G, Cumbo E, Ferrari M. Surface debris of canal walls after post space preparation in endodontically treated teeth: A scanning electron microscopic study. Oral Surg Oral Med Oral Pathol Oral Radiol Endod 2004;97:381387.

2. Coniglio I, Magni E, Goracci C, Radovic I, Carvalho CA, Grandini I, Ferrari M. Post space cleaning using a new nickel titanium endodontic drill combined with different cleaning regimens. J Endod 2008;34:83-86.

3. Boone KJ, Murchinson DF, Schindler WG, Walker WA 3rd. Post retention: the effect of sequence of post space preparation, cementation time and different sealers. J Endod 2001;27:768-771

4. Gu XH, Mao CY, Kern M. Effect of different irrigation on smear layer removal after post space preparation. J Endod 2009;35:583-586

5. Maroulakos G, He J, Nagy WW. The post-endodontic adhesive interface: theorical perspectives and potential flaws. J Endod 2018;44:363-371

6. Frajlich S, Goldberg F, Massone E, Cantarini C, Artaza L. Comparative study of retreatment of Thermafil and lateral condensation endodontic fillings. Int Endod J 1998;31:354357

7. Ma J, Al-Ashaw AJ, Shen Y, Gao Y, Yang Y, Zhang Ch, Haapasalo M. Efficacy of ProTaper Universal rotary retreatment system for gutta-percha removal from oval root canals: A Micro-computed tomography study. J Endod 2012;38:1516-1520

8. Long W, Li J, Liu Y, Jiang H . Effect of obturation technique with immediate and delayed post space preparation on apical voids and bond strength of apical gutta-percha. J Int Med Res 2019;47:470-480

9. Poletto D, Poletto AC, Cavalaro A, Machado R, CosmeSilva L, Dezan Garbelini CC, Hoeppner MG. Smear layer removal by different chemical solutions used with or without ultrasonic activation after post preparation. Restor Dent Endod 2017;42:324-331

10. Weller RN, Brady JM, Bernier WE. Efficacy of ultrasonic cleaning. J Endod 1980;6:740-743

11. Sanabria-Liviac D, Moldauer BI, Garcia-Godoy F, Campos AA, Casaretto M, Torres-Navarro J, Scalercio JM. Comparison of the XP-Endo Finisher File System and Passive Ultrasonic Irrigation (PUI) on Smear Layer
Removal after Root Canal Instrumentation. J Dent Oral Health 2017;4:1-7

12. Silva EJNL, Belladonna FG, Zuolo AS, Rodrigues E, Ehrhardt IC, Souza EM, De-Deus G. Effectiveness of XPendo Finisher and XP-endo Finisher $\mathrm{R}$ in removing root filling remnants: a micro-CT study. Int Endod J 2018;51: 86-91

13. Zand V, Mokhtari H, Reyhani Mf, Nahavandizadeh N, Azimi S. Smear layer removal evaluation of different protocol of Bio Race file and XP-endo Finisher file in corporation with EDTA 17\% and NaOCl. J Clin Exp Dent 2017; 9:1310 1314

14. Hagge MS, Wong RD, Lindemuth JS. Effect of three root canal sealers on the retentive strength of endodontic posts luted with a resin cement. Int Endod J 2002;35:372-378

15. Azimian S, Bakhtiar $\mathrm{H}$, Azimi S, Esnaashari E. In vitro effect of XP-endo Finisher on the amount of residual debris and smear layer on the root canal walls. Dent Res J 2019; 16:179-184

16. Guerisoli DMS, Marchesan MA, Walmsley AD, Lumley PJ, Pecora JD. Evaluation of smear layer removal by EDTAC and sodium hypochlorite with ultrasonic agitation. Int Endod J 2002;35:418-421

17. Guo X, Miao H, Li L, Zhang S, Zhou D, Lu Y, Wu L. Efficacy of four different irrigation techniques combined with $60^{\circ} \mathrm{C} 3 \%$ sodium hypochlorite and $17 \%$ EDTA in smear layer removal. BMC Oral Health 2014;14:114

18. Chen X, Liu H, He Y, Luo T, Zou L. Effects of endodontic sealers and irrigation systems on smear layer removal after post space preparation. J Endod 2018; 44:1293-1297

19. Goldberg F, Frajlich S, Balzano, Rocca M, Valverde M. Estudio comparativo de la limpieza de las preparaciones para anclaje intrarradicular inmediatas y mediatas. Rev Asoc Odontol Argent 2004;92:36-39

20. Schäfer E, , Schrenker C, Zupanc J, Bürklein S. Percentage of gutta-percha filled areas in canals obturated with crosslinked gutta-percha core-carrier systems, single-cone and lateral compaction technique. J Endod 2016; 42:294-298

21. Iglecias EF, Gonzalez Freire L, de Miranda Candeiro GT, et al. Presence of Voids after Continuous Wave of Condensation and Single-cone Obturation in Mandibular Molars: A Micro-computed Tomography Analysis. J Endod 2017; 43:638-642 